\title{
Pemberdayaan Masyarakat dalam Pengolahan Limbah Cair Produksi Tempe di Kampung Tempe Kota Tangerang
}

\author{
Analekta Tiara Perdana ${ }^{1 *}$, Dina Widiawati² \\ ${ }^{I}$ Program studi Biologi, Fakultas Sains dan Teknologi, Universitas Al Azhar Indonesia, \\ Jalan Sisingamangaraja Kebayoran Baru Jakarta Selatan, 12110 \\ ${ }^{2}$ Program studi Teknologi Pangan, Fakultas Sains dan Teknologi, Universitas Al Azhar Indonesia, \\ Jalan Sisingamangaraja Kebayoran Baru Jakarta Selatan, 12110 \\ Email Penulis Korespondensi: lektatiara@uai.ac.id
}

\begin{abstract}
Kampung Tempe, Koang Jaya, Karawaci, Tangerang, Banten is one of industrial center for tempe production. Basically, tempe industry produce waste in form of liquid and solid wastes that potentially cause environmental pollution. Solid waste can be used as animal feed, while liquid waste is directly discharged into the environment without prior processing. Kampung tempe produced liquid waste approximately 500-2000 L per day. Therefore, it is necessary to process liquid waste, one of which is into liquid organic fertilizer. The aims of this activity are to conduct community development of liquid waste processing into liquid organic fertilizer. The steps of community development are including preparation and implementation through socialization and education. The result showed an increase of knowledge and skills in liquid waste processing into liquid organic fertilizer by $90 \%$, as well as the reduction of liquid waste amount that is converted into liquid organic fertilizer by $5 \%$. The processing of liquid waste from tempe production is expected to be carried out continuously to reduce environmental pollution.
\end{abstract}

\section{Keywords: Industry, Kampung Tempe, Liquid Organic Fertilizer, Liquid Waste, Tempe.}

\begin{abstract}
Abstrak
Perkembangan industri tempe di Kota Tangerang didukung oleh salah satu sentra industri tempe yaitu Kampung Tempe, Koang Jaya, Karawaci, Tangerang, Banten. Industri tempe pada dasarnya akan menghasilkan limbah, baik berupa limbah cair maupun limbah padat yang berpotensi menimbulkan pencemaran lingkungan. Limbah padat hasil produksi tempe dapat dimanfaatkan sebagai pakan ternak, sedangkan limbah cair hasil produksi tempe langsung dibuang ke lingkungan tanpa dilakukan pengolahan terlebih dahulu. Limbah cair hasil produksi tempe di Kampung Tempe Kota Tangerang diperkirakan mencapai 500-2000 L per hari. Oleh karena itu perlu dilakukan pengolahan limbah cair hasil produksi tempe, salah satunya menjadi pupuk organik cair (POC). Kegiatan ini bertujuan untuk melakukan pemberdayaan masyarakat terkait pengolahan limbah cair hasil produksi tempe menjadi POC. Tahapan pemberdayaan masyarakat meliputi persiapan serta pelaksanaan kegiatan melalui sosialisasi dan edukasi. Hasil dari kegiatan ini menunjukkan peningkatan pengetahuan dan keterampilan dalam mengolah limbah cair hasil produksi tempe menjadi POC sejumlah $90 \%$, serta pengurangan jumlah limbah cair hasil produksi tempe yang diolah menjadi POC sejumlah $5 \%$. Pengolahan limbah cair hasil produksi tempe diharapkan dapat dilakukan terus menerus untuk mengurangi pencemaran lingkungan.
\end{abstract}

Kata kunci: Industri, Kampung Tempe, Limbah Cair, POC, Tempe. 


\section{PENDAhUluan}

Industri tempe merupakan industri rumah tangga (IRT) yang banyak dijumpai di Indonesia. IRT ini biasa dilakukan di daerah pemukiman penduduk, salah satunya di Kampung Tempe Kelurahan Koang Jaya, Kecamatan Karawaci, Kota Tangerang, Provinsi Banten. Terdapat sejumlah 33 kepala keluarga (KK) dari sekitar $60 \mathrm{KK}$ di Kampung Tempe berprofesi sebagai produsen tempe yang berlokasi dari blok A-C. Masing-masing blok tersebut memiliki kapasitas produksi berbedabeda dengan jumlah limbah yang dihasilkan pun bervariasi. Profil produksi tempe di Kampung Tempe disajikan pada Tabel 1.

Tabel 1. Langkah pelaksanaan kegiatan

\begin{tabular}{llll}
\hline Lokasi & $\begin{array}{l}\text { Jumlah } \\
\text { Industri }\end{array}$ & $\begin{array}{l}\text { Kapasitas } \\
\text { Produksi } \\
\text { (kg/hari) }\end{array}$ & $\begin{array}{l}\text { Limbah } \\
\text { (L/hari) }\end{array}$ \\
\hline $\begin{array}{l}\text { Blok } \\
\text { A }\end{array}$ & 12 & $50-200$ & $500-1000$ \\
$\begin{array}{l}\text { Blok } \\
\text { B }\end{array}$ & 11 & $100-150$ & $1000-1500$ \\
$\begin{array}{l}\text { Blok } \\
\text { C }\end{array}$ & 10 & $100-200$ & $1500-2000$ \\
\hline
\end{tabular}

Proses produksi tempe membutuhkan jumlah air yang banyak, baik untuk tahap perebusan, perendaman, pencucian maupun peragian. Kebutuhan jumlah air yang tinggi dalam proses produksi tempe sejalan dengan jumlah limbah cair yang dihasilkan. Limbah cair tersebut berupa air sisa perebusan, perendaman, pencucian serta peragian kedelai yang dibuang langsung ke saluran air di tempat produksi tempe sehingga berpotensi mencemari lingkungan, sehingga perlu dilakukan pengolahan. Limbah cair hasil produksi tempe disajikan pada Gambar 1.

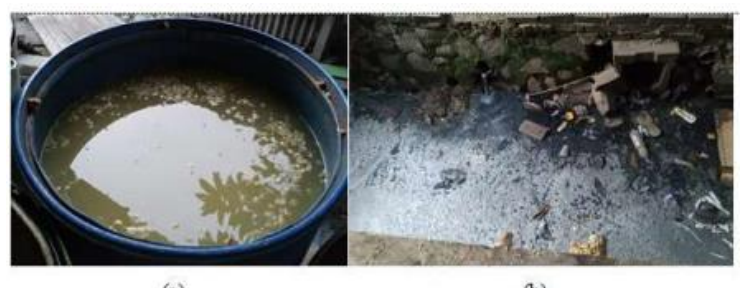

(b)

Gambar 1. (a) Limbah cair hasil produksi tempe, (b) tempet pembuangan limbah cair hasil produksi tempe.

Limbah cair hasil produksi tempe memiliki karakteristik berupa bahan organik padatan tersuspensi. Bagian padat atau limbah padat dapat dijadikan sebagai pakan ternak dan bagian cair atau limbah cair dapat dijadikan pupuk cair (Krinadianto, 2019). Jika limbah hasil produksi tempe dibuang langsung ke lingkungan, maka akan menimbulkan bau tidak sedap akibat proses fermentasi limbah organik tersebut (Lestari et al., 2021). Inovasi pengolahan limbah cair hasil produksi tempe diharapkan dapat menjadi salah satu solusi untuk mengurangi pencemaran lingkungan.

Salah satu metode pengolahan limbah cair hasil produksi tempe adalah dengan memanfaatkannya menjadi pupuk organik cair (POC) (Prasetio \& Widyastuti, 2020). POC dari limbah cair hasil produksi tempe berfungsi sebagai sumber makanan bakteri. Selain itu, apabila pembuatan POC ini ditambahkan effective inoculant atau aktivator dapat meningkatkan keragaman mikroba tanah (Supinah et al., 2020).

Berdasarkan pemaparan di atas, masalah yang ingin diselesaikan adalah limbah cair hasil produksi tempe yang dibuang langsung ke lingkungan akan mencemari lingkungan. Oleh karena itu perlu dilakukan pemberdayaan masyarakat terkait pengolahan limbah cair produksi tempe menjadi POC. Kegiatan ini diharapkan dapat meningkatkan pengetahuan dan keterampilan dalam mengolah limbah cair produksi tempe menjadi POC serta pengurangan jumlah limbah cair produksi tempe.

\section{METODE}

\section{Waktu dan Tempat Pelaksanaan}

Kegiatan ini dilaksanakan di Kampung Tempe, Kelurahan Koang Jaya, Kecamatan Karawaci, Kota Tangerang, Banten. Kegiatan dilakukan selama 3 hari pada hari Jum'at 22 Oktober 2021 serta Sabtu, 23 dan 30 Oktober 2021 pukul 10.00-12.00 WIB. Peserta yang terlibat dalam kegiatan ini adalah para perajin tempe sejumlah 10 orang.

\footnotetext{
Alat dan Bahan:

Alat yang digunakan untuk membuat POC adalah botol HDPE $500 \mathrm{~mL}$ yang sudah diberi label, gelas ukur $500 \mathrm{~mL}$ serta corong. Bahan yang digunakan untuk membuat POC adalah air sisa perendaman kedelai serta akuades.
} 


\section{Langkah Pelaksanaan}

Langkah pelaksanaan kegiatan disajikan pada Tabel 2.

Tabel 2. Langkah pelaksanaan kegiatan

\begin{tabular}{|c|c|c|}
\hline $\begin{array}{l}\text { Tahapa } \\
\mathrm{n}\end{array}$ & Rincian & Hasil \\
\hline $\begin{array}{l}\text { Persiap } \\
\text { an } \\
\text { kegiata } \\
\text { n }\end{array}$ & $\begin{array}{ll}\text { - } & \text { Analisis } \\
\text { kondisi } \\
\text { lingkungan } \\
\text { - Analisis } \\
\text { limbah cair } \\
\text { hasil } \\
\text { produksi } \\
\text { tempe }\end{array}$ & $\begin{array}{l}\text { Hasil analisis } \\
\text { lingkungan dan } \\
\text { hasil analisis } \\
\text { limbah cair hasil } \\
\text { produksi tempe }\end{array}$ \\
\hline $\begin{array}{l}\text { Pelaks } \\
\text { anaan } \\
\text { kegiata } \\
n\end{array}$ & 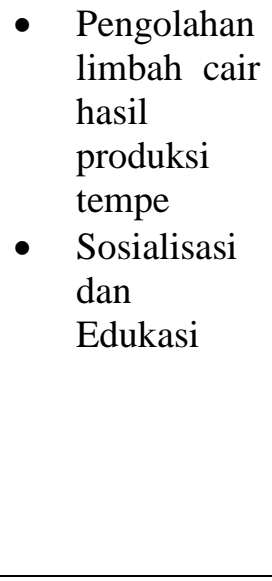 & 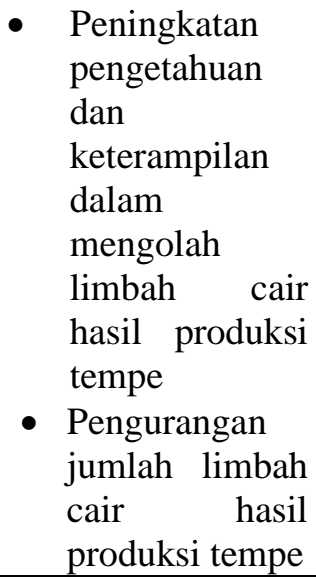 \\
\hline
\end{tabular}

Persiapan kegiatan dilakukan dengan menganalisis kondisi lingkungan melalui wawancara mitra serta pengambilan sampel limbah cair pada setiap tahap produksi tempe (perebusan, perendaman, pencucian serta peragian kedelai) untuk dianalisis. Pelaksanaan kegiatan dilakukan dengan mengolah limbah cair hasil produksi tempe menjadi POC dengan percobaan pada tanaman kangkung kemudian melakukan sosialisasi dan edukasi pengolahan limbah cair produksi tempe menjadi POC. Hasil sosialisasi dan edukasi diukur berdasarkan hasil analisis kuesioner.

\section{HASIL DAN PEMBAHASAN}

\section{Persiapan Kegiatan}

Persiapan kegiatan meliputi analisis lingkungan serta analisis limbah cair hasil produksi tempe. Hasil analisis lingkungan menunjukkan seluruh perajin tempe membuang limbah cair hasil produksi tempe secara langsung ke lingkungan. Limbah padat hasil produksi tempe dimanfaatkan sebagai pakan ternak. Hasil analisis limbah cair pada setiap tahap produksi tempe (perebusan, perendaman, pencucian serta peragian kedelai) berdasarkan parameter Biological Oxygen Demand (BOD) dan Chemical Oxygen Demand (COD) disajikan pada Tabel 3.

Tabel 3. Hasil analisis limbah cair produksi tempe

\begin{tabular}{lll}
\hline Limbah Cair & $\begin{array}{l}\text { BOD } \\
(\mathrm{mg} / \mathrm{L})\end{array}$ & COD $(\mathrm{mg} / \mathrm{L})$ \\
\hline Perebusan & 15774 & 52579 \\
Perendaman & 13636 & 45454 \\
Pencucian & 450 & 1493 \\
Peragian & 230 & 867 \\
Kontrol & 3.97 & 27.9 \\
\hline
\end{tabular}

Baku mutu air limbah industri tempe didasarkan pada Peraturan Menteri Lingkungan Hidup Republik Indonesia No.5 Tahun 2014 Tentang Baku Mutu Air Limbah, yaitu 150 $\mathrm{mg} / \mathrm{L}$ untuk BOD dan $300 \mathrm{mg} / \mathrm{L}$ untuk COD (Sayow et al., 2020). Berdasarkan hasil analisis limbah cair produksi tempe, seluruh limbah cair melebihi baku mutu yang sudah ditetapkan.

BOD merupakan parameter pengukuran beban limbah, penentuan dampak pembuangan pada air, pengukuran jumlah oksigen yang dikonsumsi oleh mikroorganisme dalam zat organik yang terurai di dalam air. Semakin besar jumlah BOD, semakin cepat oksigen habis di dalam air. Ini berarti lebih sedikit oksigen yang tersedia bagi ekosistem air. COD merupakan parameter pengukuran oksigen yang diperlukan untuk mengoksidasi zat organik yang larut dan partikulat dalam air. Semakin tinggi COD berarti lebih banyak bahan organik teroksidasi dalam sampel, yang akan mengurangi kadar oksigen terlarut. Pembuangan limbah cair secara langsung tanpa pengolahan akan mempengaruhi kualitas air. Kualitas air yang tidak sesuai standar mutu yang ditetapkan akan berdampak buruk terhadap manusia dan sistem ekologi (Sari \& Rahmawati, 2020).

\section{Pelaksanaan Kegiatan}

Limbah cair yang digunakan sebagai bahan dasar POC adalah limbah cair sisa perendaman kedelai. Hal ini didasari oleh pengamatan pada pertumbuhan tanaman kangkung yang diberi perlakuan POC limbah cair pada setiap tahap produksi tempe (perebusan, perendaman, pencucian serta peragian kedelai) dengan interval penyiraman 2 minggu selama 4 minggu (Gambar 2). 


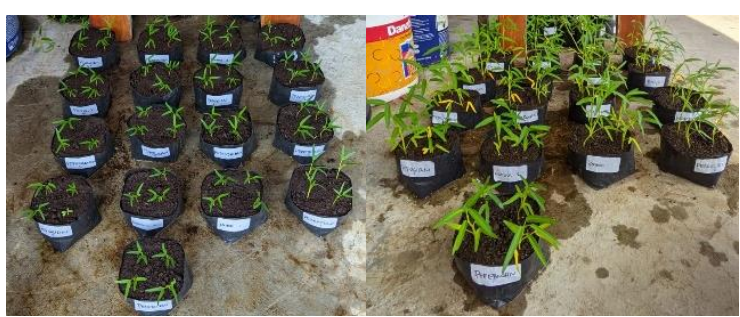

(a)

(b)

Gambar 2. Pertumbuhan tanaman kangkung (a) 1 minggu, (b) 3 minggu.

POC limbah cair dari tahap perendaman menghasilkan tinggi tanaman, diameter batang, jumlah daun, berat basah batang, berat kering batang dan daun tertinggi pada tanaman kangkung. POC dibuat dengan perbandingan $20 \%$ limbah cair dan $80 \%$ akuades. POC tersebut dapat langsung diaplikasikan ke tanaman. POC yang sudah dibuat disajikan pada Gambar 3. Pertumbuhan tanaman kangkung darat (Ipomoea reptans) dengan perlakuan variasi konsentrasi limbah cair industri tempe menunjukkan hasil yang baik dan konsentrasi limbah cair industri tempe yang efektif untuk pertumbuhan tanaman kangkung darat adalah $60 \%$ (Salamah et al., 2009).

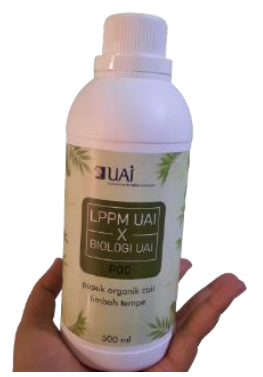

Gambar 3. Pupuk organik cair limbah tempe.

Sosialisasi dan edukasi pengolahan limbah cair produksi tempe dilakukan dengan metode ceramah dan demonstrasi pada 10 orang perajin tempe (Gambar 4). Sosialisasi dan edukasi dilakukan secara langsung dengan mendatangi pabrik tempe tempat perajin memproduksi tempe satu per satu. Sebelum sosialisasi dan edukasi dilakukan, peserta diberikan kuesioner terkait pengetahuan dan keterampilan dalam mengolah limbah cair produksi tempe. Hasil dari kuesioner tersebut menunjukkan seluruh peserta membuang limbah cair hasil produksi tempe ke lingkungan tanpa dilakukan pengolahan. Peserta juga tidak mengetahui bagaimana cara mengolah limbah tersebut.
Metode ceramah saat sosialisasi dan edukasi dilakukan dengan cara pemberian teori tentang pemanfaatan limbah cair hasil produksi tempe menjadi POC. Setelah selesai pemberian teori dilanjutkan dengan demonstrasi pembuatan POC. Para perajin tempe menyambut dengan antusias. Hal ini dibuktikan dengan banyaknya pertanyaan yang diberikan terkait pengolahan limbah cair hasil produksi.

Setelah sosialisasi dan edukasi dilakukan, peserta dibagikan kuesioner kembali. Seminggu setelah kegiatan sosialisasi dan edukasi, penurunan jumlah limbah cair produksi tempe yang diolah menjadi POC dievaluasi. Hasil dari kegiatan ini menunjukkan peningkatan pengetahuan dan keterampilan dalam mengolah limbah cair hasil produksi tempe menjadi POC sejumlah $90 \%$ yaitu dari $0 \%$ menjadi $90 \%$, serta pengurangan jumlah limbah cair hasil produksi tempe yang diolah menjadi POC sejumlah $5 \%$, yaitu dari $100 \%$ menjadi $95 \%$.

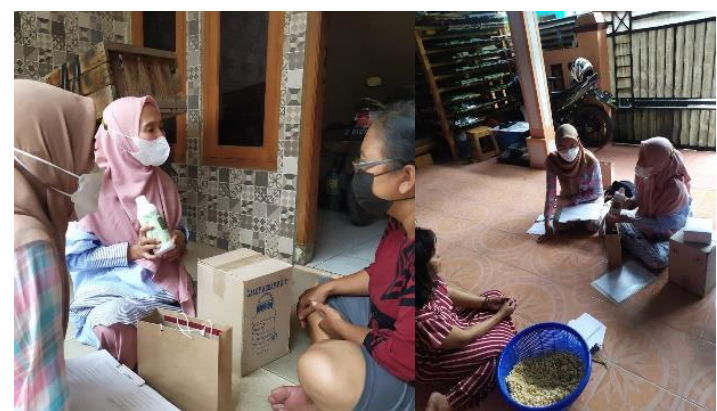

Gambar 4. Kegiatan sosialisasi dan edukasi.

\section{SIMPULAN DAN SARAN}

Sosialisasi dan edukasi pengolahan limbah produksi tempe sebagai POC berhasil dilakukan dengan peningkatan pengetahuan dan keterampilan dalam mengolah limbah cair hasil produksi tempe menjadi POC sejumlah 90 $\%$, serta pengurangan jumlah limbah cair hasil produksi tempe yang diolah menjadi POC sejumlah $5 \%$. Pengolahan limbah cair hasil produksi tempe diharapkan dapat dilakukan terus menerus untuk mengurangi pencemaran lingkungan.

\section{UCAPAN TERIMA KASIH}

Ucapan terima kasih disampaikan kepada Universitas Al Azhar Indonesia serta LPPM Universitas Al Azhar Indonesia yang telah memfasilitasi kegiatan baik dari segi moril 
maupun materil. Ucapan terima kasih disampaikan kepada mitra, terutama CV Tempe $\mathrm{H}$ Joyo serta mahasiswa yang terlibat atas kontribusi dalam setiap rangkaian kegiatan.

\section{DAFTAR PUSTAKA}

Guna, T. T. (2019). Andri Krinadianto. 2, 219 223.

Kelurahan, D. I., Kecamatan, U., Kabupaten, K., \& Augustine, K. D. (2020). Limbah Tahu 1. 16, 245-252.

Lebar, D. P. (2021). Surya abdimas. 5(1), 2227.

Prasetio, J., \& Widyastuti, S. (2020). Pupuk Organik Cair Dari Limbah Industri Tempe. WAKTU: Jurnal Teknik UNIPA, 18(2), 2232.

https://doi.org/10.36456/waktu.v18i2.2740
Salamah, Z., Wahyuni, S. T., \& Utami, L. B. (2009). Pemanfaatan Limbah Cair Industri Tempe Untuk Meningkatkan Pertumbuhan Tanaman Kangkung Darat ( Ipomoea reptans, Poir ). Prosiding Seminar Nasional Penelitian, Pendidikan Dan Penerapan MIPA, 280-286.

Sari, D., \& Rahmawati, A. (2020). Pengelolaan Limbah Cair Tempe Air Rebusan dan Air Rendaman Kedelai. Jurnal Ilmiah Kesehatan Media Husada, 9(1), 47-54. https://doi.org/10.33475/jikmh.v9i1.210

Supinah, P., Setiawan, W. F., \& Pratika Mulya, S. (2020). Sosialisasi Pemanfaatan Limbah Tempe Sebagai Pupuk Organik Cair Untuk Pengolahan Berkelanjutan di Desa Kuripan Kertoharjo. Jurnal Pusat Inovasi Masyarakat, 2(4), 642-646. 